\title{
EFEKTIVITAS PELATIHAN MOTIVASI TERHADAP PENINGKATAN PRODUKTIVITAS KARYAWAN BAGIAN EXPECTING PT X
}

\author{
Tri Noviana Rini \& Herlina Siwi Widiana \\ Fakultas Psikologi \\ Universitas Ahmad Dahlan \\ J1 Kapas No. 9 Yogyakarta \\ herlinasiwi@uad.ac.id
}

\begin{abstract}
This research was quasi experimental research aimed at knowing the effectiveness of motivation training to increase productivity. This research used non-randomized pretest-posttest control group design. The research subjects were 26 employees of Expecting Division (Quality Control) PT $\mathrm{X}$ with low productivity. They were randomly divided in two groups, experiment group and control group. Independent Sample T Test was used to analyze change productivity from gained score. The result shows there's significant difference between experiment group and control group after training $(\mathrm{t}=2.778, \mathrm{p}=0.010, \mathrm{p}<0.05)$. The research result shows that motivation training is effective to increase productivity.
\end{abstract}

Keywords: Expecting Division, Motivation Training, Productivity.

\begin{abstract}
Abstrak
Penelitian ini menggunakan eksperimen dengan desain eksperimen yang dipakai adalah quasi-experiment yang bertujuan untuk mengetahui efektivitas pelatihan motivasi terhadap peningkatan produktivitas karyawan bagian Expecting (Quality Control) PT. X. Model rancangan yang digunakan adalah non-randomi ed pretest-posttest control group design. Subjek penelitian adalah 26 orang karyawan bagian expecting yang memiliki produktivitas kerja di bawah rata-rata yang dibagi ke dalam kelompok eksperimen dan kelompok kontrol. Analisis data menggunakan t-test independent sample. Berdasarkan hasil analisis diketahui bahwa terdapat perbedaan peningkatan produktivitas kerja karyawan yang sangat signifikan antara kelompok eksperimen yang mendapat pelatihan motivasi
\end{abstract}


dan kelompok kontrol yang tidak mendapat pelatihan motivasi $(\mathrm{t}=2,778$; $\mathrm{p}=0,010 ; \mathrm{p}<0,05)$. Hasil penelitian menunjukkan pelatihan motivasi efektif untuk meningkatkan produktivitas.

Kata kunci: Bagian Expecting, Pelatihan Motivasi, Produktivitas Kerja Karyawan.

\section{Pendahuluan}

Produktivitas merupakan salah satu aspek yang menentukan keberhasilan suatu perusahaan dalam persaingan dunia usaha yang semakin ketat (Anis dkk, 2007). Dilihat dari segi psikologi, produktivitas adalah suatu tingkah laku sebagai keluaran dari suatu proses berbagai macam komponen kejiwaan yang melatarbelakanginya (Anoraga, 2005). Pengertian produktivitas kerja adalah jumlah output yang dihasilkan seseorang secara utuh dalam satuan waktu kerja yang dilakukan meliputi kegiatan yang efektif dalam mencapai hasil atau prestasi kerja yang bersumber dari input dan menggunakan bahan secara efisien (Sinungan, 1997).

P.TX merupakan salah satu perusahaan tekstil dalam sektor pertenunan dan telah menggunakan Alat Tenun Mesin (ATM). Setiap harinya dibagi menjadi tiga shift kerja. Shift pagi jam 06.00-14.00 WIB, shift siang jam 14.00-22.00, shift malam jam 22.00-06.00 WIB. Setiap pekerja berganti shift setiap seminggu sekali. Tenaga kerja bagian produksi kurang lebih mencapai 2000 pekerja dengan jumlah ATM kurang lebih mencapai 1700 buah. Sedangkan tenaga kerja dibagian expecting/ quality control berdasarkan data produktivitas pada bulan Januari 2010 ada 108 pekerja. Setiap shift terdapat 36 pekerja dengan satu orang pengawas.

Kain yang dihasilkan PT. X adalah kain mori dan dipasarkan secara lokal. Meskipun krisis global dan perkembangan ekonomi belum stabil sekarang ini, PT. X merasa perlu untuk meningkatkan produktivitas kerja karyawannya. Hal ini dilakukan untuk memenuhi target yang telah dibuat dan mempertahankan jalannya perusahaan. Setiap harinya target yang harus didapat pada bagian expecting adalah $1200 \mathrm{~m}$ per orang. Tetapi, ada beberapa pekerja yang belum memenuhi target yang telah ditetapkan tersebut. Seperti yang diungkapkan oleh kepala bagian expecting/quality control PT X, ada 108 orang pekerja di bagian expecting/quality control yang belum memenuhi target.

Menurut Ravianto (1985), terdapat banyak faktor yang dapat mempengaruhi produktivitas diantaranya semangat kerja dan disiplin kerja, tingkat pendidikan, 
ketrampilan, gizi dan kesehatan, sikap dan etika, motivasi, iklim kerja, teknologi, sarana produksi, kesempatan kerja dan kesempatan berprestasi.

Setiap manusia mempunyai dasar alasan, mengapa seseorang bersedia melakukan jenis kegiatan atau pekerjaan tertentu. Mengapa orang yang satu bekerja lebih giat, sedangkan orang yang satunya lagi bekerja biasa saja. Tentulah semuanya ini ada dasar alasan yang mendorong yang menyebabkan seseorang bersedia bekerja seperti itu, atau dengan kata lain pasti ada motivasinya. Motivasi merupakan masalah yang sangat penting dalam setiap usaha sekelompok orang yang bekerja sama dalam rangka pencapaian tujuan tertentu (Anoraga dan Suyati, 1995).

Motivasi berasal dari kata movere yang berarti bergerak (Steers dkk, 1996). Menurut Munandar (2001), motivasi adalah suatu proses yang diawali oleh adanya kebutuhan, lalu kebutuhan tersebut mendorong seseorang untuk melakukan serangkaian kegiatan yang mengarah ketercapainya tujuan tertentu. Siagian (2002) mengungkapkan motivasi adalah daya dorong seseorang untuk memberikan kontribusi yang sebesar mungkin demi keberhasilan organisasi mencapai tujuannya.

Menurut Halonen \& Santrock (1999), motivasi adalah faktor yang membantu menjelaskan bagaimana seseorang berperilaku, berfikir, dan merasa apa yang sedang dilakukan. Motivasi merupakan hal yang sangat komplek dan berbeda pada setiap individu. Menurut Halonen dan Santrock (1999), motivasi ada dua, yaitu motivasi intrinsik dan motivasi ekstrinsik. Motivasi intrinsik adalah motif yang berasal dari kebutuhan dan keinginan dari dalam diri. Motivasi ekstrinsik adalah dorongan positif maupun negatif yang berasal dari luar yang mempengaruhi perilaku.

Motivasi merupakan kekuatan atau motor pendorong kegiatan seseorang ke arah tujuan tertentu dan melibatkan segala kemampuan yang dimiliki untuk mencapainya. Hakikatnya, motivasi karyawan dan pengusaha berbeda karena adanya perbedaan kepentingan maka perlu diciptakan motivasi yang searah untuk mencapai tujuan bersama dalam rangka kelangsungan usaha dan ketenagakerjaan, sehingga apa yang menjadi kehendak dan cita-cita kedua belah pihak dapat diwujudkan (Hamidum, 2007).

Teori penetapan tujuan (goal setting theory) (Riggio, 2003) menekankan pada tugas yang spesifik, pelaksanaan tujuan yang menantang, dan komitmen pekerja terhadap tujuan merupakan kunci pokok dari motivasi. Miner(1992), mengemukakan konsep teori penetapan tujuan dari Locke:

1) Tujuan yang sulit berperan penting terhadap peningkatan unjuk kerja dari pada tujuan yang mudah.

2) Spesifik, tujuan yang menantang berperan penting terhadap peningkatan unjuk 
kerja dari pada tidak ada tujuan atau tujuan yang tidak jelas, seperti "lakukan yang terbaik".

3) Mekanisme dari bagaimana tujuan mempengaruhi unjuk kerja adalah perhatian dan tindakan langsung, pengerahan usaha, ketekunan meningkat, termotivasi untuk mencari strategi yang tepat dalam berunjuk kerja.

4) Munculnya feedback penting untuk membuat tujuan dalam pekerjaan, karena feedback memungkinkan orang untuk membandingkan unjuk kerjanya dengan tujuan yang dibuat.

5) Komitmen terhadap tujuan penting jika tujuan mempengaruhi unjuk kerja.

6) Komitmen terhadap tujuan secara umum tidak dipengaruhi oleh keterlibatan seseorang dalam membuat tujuan pribadinya, tapi dipengaruhi dari harapan untuk sukses dan derajat kesuksesan.

7) Reward berupa uang mungkin mendorong penetapan tujuan secara spontan, mungkin berperan mempertinggi tujuan yang ditentukan, dan mungkin berperan mempertinggi komitmen terhadap tujuan.

8) Perbedaan individu seperti kepribadian dan pendidikan secara umum tidak berhubungan dengan keefektifan penetapan tujuan.

Teori penetapan tujuan (goal setting theory) (Riggio, 2003) menekankan pada tugas yang spesifik, pelaksanaan tujuan yang menantang, dan komitmen pekerja terhadap tujuan merupakan kunci pokok dari motivasi. Locke (Gibson et al, 2003) menyatakan bahwa penetapan tujuan adalah proses kognitif dari keperluan praktis. Locke (Gibson et al, 2003) menguraikan sifat proses mental (kognitif) penetapan tujuan, yaitu:

b. Perincian tujuan adalah tingkat presisi kuantitatif (kejelasan) tujuan tersebut.

c. Kesukaran tujuan adalah tingkat keahlian atau tingkat prestasi yang dicari.

d. Intensitas tujuan adalah menyangkut proses penetapan tujuan atau menentukan bagaimana mencapai tujuan tersebut.

Teori penetapan tujuan (Riggio, 2003), menyebutkan agar karyawan termotivasi, tujuan harus jelas, spesifik, dapat dicapai, dan sewaktu-waktu dapat diukur. Tujuan yang umum, seperti menyuruh pekerja untuk melakukan yang terbaik atau bekerja secepat mungkin tidak efektif untuk dilakukan. Locke, Shaw, Saari \& Latham (Riggio, 2003) mengemukakan bahwa tujuan yang cukup sulit atau menantang akan menghasilkan level motivasi yang lebih tinggi, jika tujuan telah disepakati pekerja. Menurut Erez dan Zidon (Riggio, 2003), tujuan juga tidak boleh terlalu sulit atau menantang karena akan sulit untuk dicapai oleh pekerja. Menurut Locke (Munandar, 2001), tujuan-tujuan yang cukup sulit, khusus, dan yang pernyataannya jelas, dan dapat diterima oleh tenaga kerja, akan menghasilkan unjuk kerja yang lebih tinggi daripada tujuan-tujuan yang tidak jelas, tidak khusus, dan yang mudah dicapai. Proses 
penetapan tujuan dapat dilakukan berdasarkan prakarsa sendiri atau diwajibkan oleh organisasi sebagai satu kebijakan perusahaan. Aspek penting dari model teori penetapan tujuan ini (Miner, 1992), adalah fakta bahwa penetapan tujuan itu sendiri merupakan faktor yang sangat dekat dengan tindakan atau unjuk kerja sehingga model penetapan tujuan ini merupakan prediktor yang baik pada unjuk kerja. Proses penetapan tujuan dapat dilihat dibawah ini:

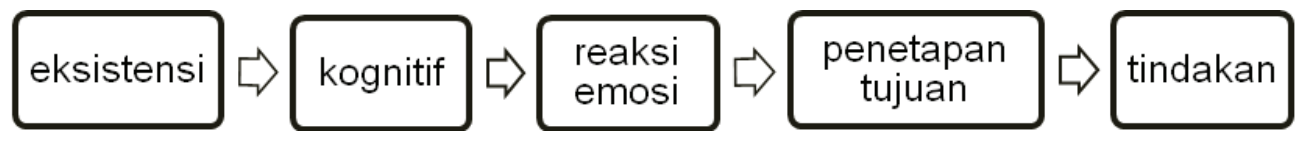

Contoh:

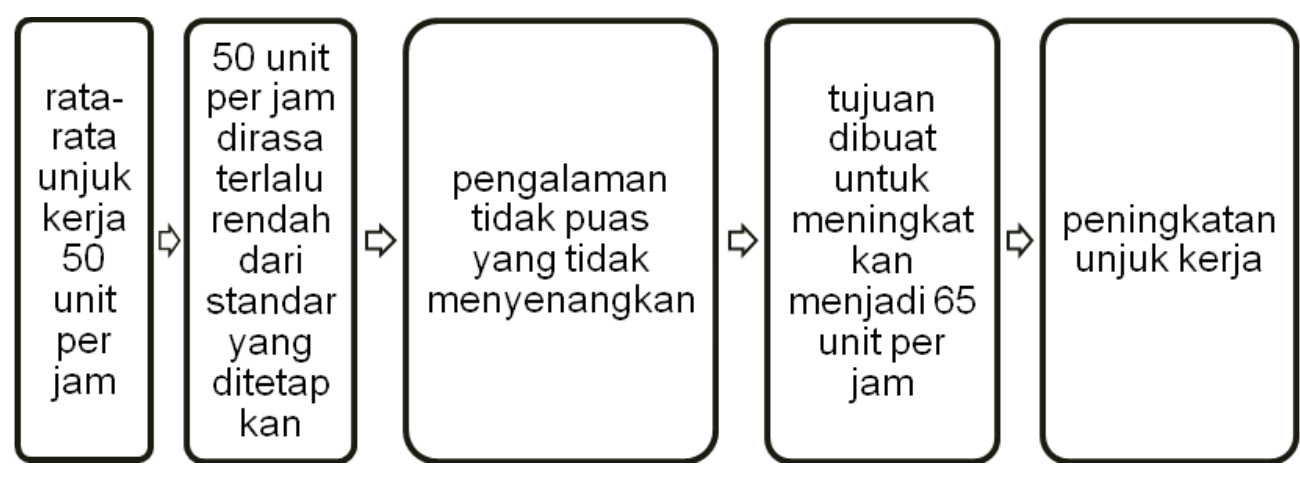

Gambar 1.

Bagan Proses Penetapan Tujuan

Penelitian tentang pengaruh kepuasan kerja dan motivasi kerja terhadap produktivitas kerja yang dilakukan oleh Djati (1999) didapatkan hasil menunjukkan bahwa variabel-variabel motivasi yang terdiri dari kebutuhan fisiologis, kebutuhan keselamatan dan keamanan kerja, kebutuhan sosial, kebutuhan penghargaan serta kebutuhan aktualisasi secara serempak menunjukkan pengaruh yang bermakna terhadap produktivitas tenaga kerja karyawan pada industri rumah tangga di Kabupaten Sidoarjo.

Berangkat dari penelitian korelasional diatas, yang menyebutkan bahwa variabel motivasi mempengaruhi variabel produktivitas kerja karyawan, dalam penelitian ini akan diuji dengan metode eksperimen. Peneliti ingin mengetahui apakah pelatihan motivasi akan meningkatkan produktivitas kerja. Peneliti tertarik untuk melakukan penelitian dengan judul 'Efektivitas Pelatihan Motivasi Terhadap Peningkatan Produktivitas Kerja Karyawan pada bagian Expecting / Quality Control di PT X. 


\section{Metode Penelitian}

Pelatihan motivasi adalah suatu kegiatan yang bermaksud untuk dapat memperbaiki dan memperkembangkan sikap, tingkah laku, ketrampilan dan pengetahuan dari para karyawannya, sesuai keinginan dari perusahaan yang bersangkutan untuk mendorong seseorang melakukan serangkaian kegiatan yang mengarah ketercapainya tujuan tertentu. Pelatihan motivasi akan diberikan kepada karyawan bagian expecting yang hasilnya dibawah target. Pelatihan motivasi didasarkan pada teori motivasi dari Locke, yaitu Teori Penetapan Tujuan (Goal Setting Theory). Pelatihan motivasi terdiri dari lima sesi yaitu: conditioning, my windows, winning ball, I have a dream, finally it sover.

Populasi dalam penelitian ini adalah karyawan bagian expecting PT X yang hasil kerjanya berada dibawah rata -rata pada bulan Juni yang berjumlah 108 orang pekerja. Sampel dalam penelitian ini adalah Karyawan bagian Expecting atau Quality Control yang hasil kerja (output) nya berada dibawah rata-rata sebanyak 30 orang. Karyawan yang hasil kerja (output) nya berada dibawah rata-rata, diambil 15 orang sebagai kelompok yang dikenai eksperimen (pelatihan) dan 15 orang sebagai kelompok yang tidak dikenai eksperimen (kontrol). Keseluruhan subjek berjenis kelamin perempuan.

Pengambilan sampel tidak dengan random dikarenakan atas kebijakan perusahaan dengan tujuan tidak mengganggu karyawan yang sedang bekerja untuk memenuhi pengejaran target. Pengambilan sampel dengan purposive sampling, yaitu pemilihan sampel sesuai dengan yang dikehendaki (Latipun, 2006).

Pengambilan data produktivitas menggunakan data internal atau dokumentasi, yaitu data yang berasal dari dalam organisasi tersebut. Data berbentuk kuantitatif yaitu data yang diukur dalam suatu skala numerik (Kuncoro, 2001). Data produktivitas diperoleh langsung dari kepala bagian expecting .

Menurut data, produktivitas kerja karyawan rata-rata yang didapat pada bulan Juni 2010, ada 108 orang pekerja yang belum memenuhi target yang ditetapkan perusahaan yaitu $1200 \mathrm{~m}$. Data dapat dilihat secara harian, mingguan, dan bulanan. Penelitian ini menggunakan data mingguan.

Materi modul diambil dari beberapa buku tentang motivasi dan game motivasi. Materi modul disusun berdasarkan proses penetapan tujuan dari teori Locke, yaitu eksistensi kognitif reaksiemosi penetapantujuan tindakan. Pertama, peserta diajak untuk mengenal potensi dirinya. Kedua, peserta diajak untuk berpikir bahwa hasil yang telah didapat selama ini kurang. Ketiga, peserta diajak untuk merasakan bahwa hasil yang kurang tersebut menimbulkan ketidakpuasan dalam diri peserta. 
Keempat, peserta diajak untuk menetapkan tujuan agar hasil yang didapat meningkat. Kelima, peserta diajak untuk melaksanakan tujuan yang telah dibuat dan diajari cara mengatasi prokarastinasi. Keenam, peserta bisa merasakan reward yang didapat dengan merencanakan semua hal yang akan dilakukan dimasa datang sehingga hasilnya lebih baik.

Penelitian ini menggunakan eksperimen dengan desain eksperimen yang dipakai adalah quasi-experiment yaitu desain eksperimen yang dilakukan tanpa randomisasi, namun masih menggunakan kelompok kontrol (Latipun, 2006). Subjek dimasukkan kedalam kelompok eksperimen dan kelompok kontrol. Kelompok eksperimen diberikan manipulasi atau perlakuan, sedangkan kelompok kontrol tidak diberikan perlakuan apapun.

Hasil dari eksperimen dianalisis dengan uji tindependent sample yaitu prosedur yang digunakan untuk membandingkan rata-rata dua group data sedangkan untuk mencari efektivitas pelatihan motivasi terhadap peningkatan produktivitas kerja analisis dengan (ANAVA) repeated measure.

\section{Hasil dan Pembahasan}

Berdasarkan hasil analisis diketahui bahwa $\mathrm{t}=2,778$ dengan skor signifikansi untuk equal variances assumed adalah $0,010(\mathrm{p}<0,05)$ maka terdapat perbedaan peningkatan produktivitas kerja karyawan yang sangat signifikan antara kelompok eksperimen dan kelompok kontrol sehingga hipotesis diterima. Hal tersebut berarti pemberian pelatihan motivasi (perlakuan) berpengaruh terhadap produktivitas kerja karyawan.

Berdasarkan hasil uji analisis data melalui Tests of Within-Subjects Effects didapatkan bahwa terdapat interaksi yang signifikan antara kelompok dan peningkatan produktivitas dengan $\mathrm{F}=8,854 ; \mathrm{p}=0,007 ; \mathrm{p}<0,05$ maka terjadi perubahan skor pretest dan postest yang berbeda antara kelompok eksperimen dengan kelompok kontrol. Nilai partial eta squared sebesar 0,270 berarti pelatihan motivasi memberikan sumbangan efektif sebesar $27 \%$ pada peningkatan produktivitas kelompok eksperimen.

Menurut Nitisemito (1991), latihan atau training adalah suatu kegiatan dari perusahaan yang bermaksud untuk dapat memperbaiki dan memperkembangkan sikap, tingkah laku, ketrampilan dan pengetahuan dari para karyawannya, sesuai keinginan dari perusahaan yang bersangkutan. Pelatihan bertujuan untuk menjadikan karyawan lebih terampil dalam bekerja sehingga karyawan mampu menghasilkan lebih banyak dan produktivitasnya meningkat. Selain itu, menurut Siagian (2002), 
alasan diadakannya suatu pelatihan (yang disebabkan menurunnya produktivitas kerja) karena pelatihan merupakan salah satu instrumen yang paling efektif untuk meningkatkan kinerja dan produktivitas kerja para karyawan dalam suatu organisasi.

Efektivitas pelatihan akan meningkat apabila berbagai prinsip pelatihan dipahami dan diterapkan dengan tepat. Prinsip-prinsip tersebut adalah partisipasi, pengulangan, relevansi, pengalihan, dan umpan balik (Siagian, 2002). Penentuan materi pelatihan yang tepat diperlukan untuk membuat suatu pelatihan tersebut efektif. Pengemasan isi pelatihan yang tepat sasaran sangat berpengaruh terhadap keberhasilan peserta dalam menyerap ilmu yang disajikan dalam pelatihan tersebut. Isi yang mudah dimengerti dan dilaksanakan akan sangat berpengaruh terhadap pemahaman peserta pelatihan sehingga tujuan diadakannya pelatihan akan tercapai. Seperti dalam teori goal setting dari Locke (Riggio, 2003), menyebutkan agar karyawan termotivasi, tujuan harus jelas, spesifik, dapat dicapai, dan sewaktu-waktu dapat diukur.

Pelatihan yang didasarkan pada teori penetapan tujuan dari Locke ini berisi tentang berbagai materi meliputi diskusi, ceramah, dan permainan. Permainanpermainan simulasi yang merangsang peserta untuk aktif dalam menentukan tujuannya sendiri serta komitmen untuk melaksanakan tujuan tersebut ditekankan dalam pelatihan ini. Sesi III dalam pelatihan ini, terutama mengajak peserta untuk menentukan tujuannya sendiri dan berkomitmen untuk melaksanakannya. Selain itu pengenalan diri melalui diskusi dalam kelompok kecil dan pemberian motivasi bagi peserta untuk meraih kesuksesan juga diajarkan dalam pelatihan ini.

Konsep isi pelatihan dibuat dengan sederhana tetapi menarik, sehingga peserta tertarik untuk ikut aktif dalam pelatihan. Permainan simulasi dirancang menarik dan menghibur, sehingga tanpa sadar peserta terhibur dengan permainan tersebut sekaligus mendapatkan ilmu. Peserta diajak untuk menentukan target yang akan dicapai dalam game simulasi sesuai dengan kemampuan dirinya sendiri. Peserta akan lebih termotivasi dan berusaha untuk mencapai target yang telah ditetapkannya sendiri. Berdasarkan hasil observasi saat pelatihan, peserta terlihat lebih semangat saat mengikuti permainan ini. Peserta antusias karena dapat berpartisipasi. Permainan lempar koin terutama sangat disukai oleh peserta. Peserta merasa terhibur karena dapat melempar koin dengan bebas, tetapi peserta juga harus melempar sebanyak mungkin sesuai target yang telah ditetapkan oleh masing-masing peserta. Hal ini menjadikan peserta merasa enjoy karena dalam suasana permainan yang menyenangkan tetapi juga serius karena harus fokus terhadap target yang telah ditetapkannya. Pelajaran ini dapat diterapkan peserta saat bekerja, yaitu perasaan enjoy dalam bekerja tetapi tetap fokus terhadap target yang telah ditetapkan perusahaan sehingga termotivasi untuk mengejar target. 
Materi pengenalan diri baik berdasarkan penilaian diri sendiri maupun orang lain juga diberikan. Materi ini bertujuan agar peserta mengetahui kelebihan dan kekurangan yang dimiliki, sehingga peserta dapat mengembangkan kelebihan yang ada dan meminimalisir kekurangan yang ada. Pemberian motivasi untuk menjadi orang sukses dan merencanakan peta hidup diajarkan agar peserta menjadi lebih semangat dan memiliki tujuan yang akan dilaksanakan. Perencanaan ini menjadikan peserta memiliki gambaran tentang masa depannya dan memaksa peserta untuk memikirkan bagaimana atau apa yang akan dilakukannya dimasa depan. Contohnya, seorang ibu yang lima tahun kedepan sudah pensiun dari perusahaan, menjadi berpikir apa yang akan beliau lakukan setelah pensiun. Ibu ini berpikir untuk berjualan bubur. Mungkin sebelumnya beliau tidak terpikir untuk berjualan bubur, tetapi dengan adanya perencanaan ini, beliau menjadi terdorong untuk mewujudkannya yaitu dengan bekerja keras agar memiliki modal untuk berjualan nantinya. Contoh lainnya, ibu-ibu yang ingin menyekolahkan anaknya sampai jenjang yang tinggi, atau membantu suami memenuhi kebutuhan rumah tangga, atau ingin membeli motor dengan uang hasil kerjanya sendiri, bahkan rencana untuk menikah. Rencana-rencana atau keinginankeinginan inilah yang dapat mendorong mereka untuk bekerja lebih giat lagi agar impian dan keinginannya dapat tercapai.

Evaluasi pelatihan juga dilaksanakan, baik evaluasi kuantitatif maupun evaluasi kualitatif. Kirkpatrick; Latham \& Saari; Warr, at al (Riggio, 2003), mengemukakan bahwa ada empat macam kriteria untuk mengevaluasi suatu keefektifan program pelatihan: kriteria reaksi, kriteria belajar, kriteria perilaku, dan kriteria hasil. Evaluasi kuantitatif dan kualitatif yaitu kriteria reaksi digunakan untuk mengukur kepuasan peserta mengikuti pelatihan, pembelajaran apa yang peserta terima, dan kesan yang peserta dapatkan yang diberikan tepat setelah pelatihan selesai. Berdasarkan evaluasi kuantitatif dan kualitatif dari peserta, setelah diadakannya pelatihan ini peserta senang dan merasa pelatihan seperti ini bermanfaat karena peserta dapat memperoleh ilmu, pengalaman baru, wawasan baru dan membangkitkan semangat untuk bekerja lebih giat lagi. Peserta merasa lebih percaya diri, berpikir kedepan, dan semangat untuk lebih maju.

Kriteria belajar dan perilaku diperoleh dari wawancara yang dilakukan setelah pelatihan. Wawancara dilakukan pada dua orang karyawan yang mengalami peningkatan produktivitas paling tinggi dan satu orang karyawan yang mengalami penurunan produktivitas paling banyak. Berdasarkan wawancara tersebut karyawan memahami tujuan diadakannya pelatihan tersebut. Karyawan tersebut mengemukakan bahwa tujuan dari pelatihan tersebut dalah motivasi untuk bekerja lebih giat lagi agar 
mencapai target. Proses pemahaman tersebut adalah kriteria belajar. Karyawan yang mengikuti pelatihan mengetahui maksud diadakannya pelatihan dengan melihat, mengamati, dan mengikuti pelatihan tersebut. Kriteria perilaku diperoleh dari cara karyawan tersebut mengaplikasikan apa yang didapat dari pelatihan kedalam pekerjaan. Dua orang karyawan yang mengalami peningkatan tertinggi mengemukakan bahwa dari pelatihan tersebut, karyawan menjadi lebih semangat dalam bekerja dan terdorong untuk mencapai target seperti karyawan lainnya. Walaupun kain yang tidak banyak cacatnya juga berpengaruh, tetapi dorongan untuk menyamai teman lain yang mencapai target menjadikan lebih semangat untuk bekerja. Sedangkan satu orang karyawan yang mengalami penurunan paling banyak mengemukakan bahwa dari pelatihan tersebut, karyawan menjadi lebih semangat dalam bekerja, tetapi menurutnya kain yang tidak banyak cacatnya merupakan pengaruh utama untuk mencapai target yang telah ditetapkan. Berdasarkan kriteria perilaku ini, nantinya dapat dilihat hasil nyatanya yaitu kriteria hasil. Kriteria hasil dilihat dari data produktivitas yang diperoleh setelah diadakannya suatu pelatihan, apakah ada perubahan atau tidak.

Berdasarkan pelatihan yang telah dilaksanakan, kenaikan produktivitas kerja karyawan terlihat pada kelompok yang diberi pelatihan. Walaupun beberapa orang dalam kelompok kontrol juga ada peningkatan dalam produktivitasnya. Berdasarkan hasil produktivitas antara kelompok eksperimen dengan kelompok kontrol menunjukkan bahwa mean pretest pada kelompok eksperimen sebesar $(M=919,62)$ sedangkan mean pretest pada kelompok kontrol sebesar $(M=1022,85)$. Setelah diberi perlakuan berupa pelatihan motivasi, terjadi peningkatan mean postest pada kelompok eksperimen. Mean postest pada kelompok eksperimen sebesar ( $\mathrm{M}=$ 976,92) dan pada kelompok kontrol sebesar $(M=976,85)$. Mean gain skor pada kelompok eskperimen sebesar $(\mathrm{M}=53,31)$ dan pada kelompok kontrol sebesar $(\mathrm{M}=-42,15)$. Hal ini membuktikan bahwa ada pengaruh pelatihan motivasi terhadap peningkatan produktivitas kerja karyawan.

Menurut Mulyono (1993), latihan dan pengembangan bagi pegawai merupakan proses pemutusan yang harus terus menerus berlangsung dalam rangka meningkatkan pengetahuan, ketrampilan, dan sikap kerja yang relevan dengan usaha-usaha memperbaiki produktivitas kerja pegawai. Oleh karena itu, tidak cukup hanya dengan satu atau dua kali diadakan pelatihan, produktivitas serta merta akan meningkat. Pelatihan sebaiknya juga diadakan dalam waktu yang intens dan tidak memiliki jarak waktu yang terlalu lama seperti pelatihan yang diadakan peneliti ini. Jeda waktu yang terlalu lama akan membuat peserta menjadi lupa karena banyaknya aktifitas pada waktu jeda tersebut. Jeda waktu ini juga membuat modul yang seharusnya runtut 
menjadi tidak efektif. Sesi I sampai III yang banyak aktif dalam permainan akan dicoolingdown pada sesi IV dengan melihat video motivasi, melihat impian, dan merencanakan masa depan. Tetapi pada kenyataannya hari pertama yang berisi sesi I-III terasa menyenangkan dan seru. Tetapi hari kedua yaitu sesi IV-V terasa membosankan karena dari awal materi sudah santai dan tidak banyak aktifitas yang dilakukan. Hal ini membuat peserta menjadi bosan walaupun juga mengasyikkan bagi beberapa peserta. Pelatihan yang berkesinambungan dan pemunculan faktorfaktor lain yang dapat meningkatkan produktivitas kerja karyawan didukung dengan menejemen yang baik dari perusahaan akan membuat karyawan dapat mencapai target yang ditetapkan perusahaan.

\section{Simpulan}

Simpulan dari penelitian ini adalah ada perbedaan peningkatan produktivitas kerja karyawan yang sangat signifikan antara kelompok eksperimen dan kelompok kontrol. Sumbangan efektif pelatihan motivasi terhadap peningkatan produktivitas kerja karyawan sebesar $27 \%$. Peningkatan produktivitas kerja karyawan yang mendapatkan pelatihan motivasi lebih tinggi daripada peningkatan produktivitas kerja karyawan yang tidak mendapatkan pelatihan motivasi. Hal ini membuktikan bahwa produktivitas kerja karyawan dapat ditingkatkan dengan pelatihan motivasi.

\section{Daftar Pustaka}

Anis, M; Nandiroh, S; \& Supriyanto, A. (2007). Usaha Peningkatan Produktivitas dengan Productivity Evaluation Tree (PET) Models. Jurnal Ilmiah Teknik Industri, 5, 3, 106-112. http://eprints.ums.ac.id/ 816/1/jiti0503 02OK.pdf. Diakses tanggal 2 April 2010.

Anoraga, P. (2005). Psikologi Kerja. Jakarta: PT. Rineka Cipta.

Anoraga, P \& Suyati, S. (1995). Psikologi Industri dan Sosial. Jakarta: Pustaka Jaya.

Djati, S. P. (1999). Pengaruh Variabel-Variabel Motivasi Terhadap Produktivitas Tenaga Kerja Karyawan pada Industri Rumah Tangga di Kabupaten Sidoarjo. Jurnal Manajemen dan Kewirausahaan Vol. 1, 1, 22 35. http:/ /puslit. petra.ac.id/journals/management/. Diakses Tanggal 18 November 2009. 
Gibson, J. L; Ivancevich, J. M \& Donnelly, J. H. (2003). Organisasi: Perilaku, Struktur, Proses, Jilid 1, Edisi Kelima. Jakarta: Erlangga

Halonen, J. S \& Santrock, J. W. (1999). Psychology: Context and Application, Edisi Ketiga. New York: McGraw Hill.

Hamidum. (2007). Produktivitas Kerja. http://hamidum.wordpress.com/2007/11/ 27/ produktivitaskerja. 29 September 2009.

Kuncoro, M. (2001). Metode Kuantitatif Teori dan Aplikasi Untuk Bisnis dan Ekonomi. Yogyakarta: Unit Penerbit dan Percetakan AMP YKPN.

Latipun. (2006). Psikologi Eksperimen, Edisi Kedua. Malang: UMM Press.

Miner, J. B. (1992). Industrial Organi ational Psychology. Singapore: McGraw Hill.

Mulyono, M. (1993). Penerapan Produktivitas dalam Organisasi. Jakarta: Bumi Aksara.

Munandar, A. S. (2001). Psikologi Industri dan Organisasi. Jakarta: UI Press

Nitisemito, A. S. (1991). Manajemen Personalia (Manjemen Sumber Daya Manusia). Jakarta: Ghalia Indonesia.

Ravianto, J. (1985). Produktivitas dan Manajemen, Seri Produktivitas IV. Jakarta: Lembaga Sarana Informasi Usaha dan Produktivitas.

Riggio, R. E. (2003). Introduction to Industrial/Organizational Psychology. New Jersey: Prentice Hall.

Siagian, S. P. (2002). Kiat Meningkatkan Produktivitas Kerja. Jakarta: Rineka Cipta.

Sinungan, M. (1997). Produktivitas Apa dan Bagaimana. Jakarta: Bumi Aksara.

Steers, R. M; Porter, L. W; \& Bigley, G. A. (1996). Motivation and Leadership atau Work. New York: McGraw Hill. 